\title{
Theology of Climate Change Mitigation and Adaptation: The Place of the Church
}

\author{
Benjamin C.D. Diara \\ Department of Religion and Cultural Studies \\ University of Nigeria, Nsukka-Nigeria \\ Nche George Christian \\ Department of Religion and Cultural Studies \\ University of Nigeria, Nsukka- Nigeria
}

\section{Doi:10.5901/ajis.2013.v2n13p85}

\begin{abstract}
In this age of technology characterized by capitalist and materialist culture, Christian ministry pertaining to the natural world of creation has been relegated to the background in the teaching and preaching of many churches whereas on the other hand, it has long been held that the environment is among the most pressing concerns of this generation. While most Christians appreciate the beauty of nature, many do not realize that there is a strong biblical basis for creation care, and that, in fact, many ethical values, fundamental to the development of a peaceful society, are particularly relevant to the ecological question. The purpose of this research is twofold, firstly, to establish the basis for the Church's response to the problem of climate change by correlating climate change with the Biblical mandate for creation care and secondly, to provide recommendations on how creation care can be integrated into the local church's administration and ministry. Recent scientific findings on climate change alongside its environmental and social implications provided the framework upon which this research is based. The significance of the research is that it has provided a document that spells out clearly why and how Christian Churches should be involved in tackling the issue of climate change and the resultant ecological problems facing the world today.
\end{abstract}

Keywords: biblical theology, climate change, creation, anthropogenic, mitigation.

\section{Introduction}

The Scripture clearly echoes man's responsibility to his environment in Genesis 2: 15, "Then the Lord God took the man and put him in the Garden of Eden to tend and keep it". Thus, humanity and in particular, Christians, are required under God to tend and to keep the ecology and this includes taking measures to prevent environmental disasters. To this effect, Christian theological reflections place repeated emphasis on the goodness of creation and on humankind's role in working for and with God in the process of "repairing" creation. Christians are called to respect God's world, to model the life of Christ, and to live in the hope and joy of what God, in Christ, has done for "all things".

The challenges of climate change to the human ecology are overwhelming. In the whole world today, there are clear evidences of increase in climate change induced environmental hazards that invariably militate against the natural as well as the socio-economic security of most nations of the world. Persistent droughts and flooding, off season rains and dry spells have become common phenomena today. For instance, in south eastern states of Nigeria, the impacts of climate 
change include heat stress, absence of harmattan, unpredictable rainfall patterns, heavier rains, gully erosion, flooding and landslides. In addition to other factors, these hazards have affected soil fertility, water and forest resources, settlement infrastructure and farmlands (Madu, 2011).

Although the environmental challenges facing man today are daunting, a faithful Christian response recognizes the hope in Christ and his work, and the joy inherent in a way of life that liberates us from the relentless pursuit of consumption for its own ends, and enables us to live lives of "shalom" or full human flourishing. Every Christian therefore has a divine mandate to be committed to actions that are geared towards climate change mitigation and adaptation and other forms of ecological protection activity.

\section{The Concept of Climate Change}

Strictly speaking there is no such thing as a "normal climate" or average climate, for as the weather changes from day to day, so also does the climate change from year to year (Anyadike, 2009). It is therefore a known fact that the world's climate has always been changing between hotter and cooler periods due to various factors. However, recent evidence and predictions indicate that climate changes are accelerating and will lead to wide-ranging shifts in climate variables.

The concept of climate change has taken a new dimension since the discovery of the facts of global warming in 2007. The Inter governmental Panel on Climate Change (IPCC) (2001), refers to climate change as any change in climate over time, whether due to natural variability or as a result of human activity. In 2007 the Fourth Assessment Report of the Intergovernmental Panel on Climate Change (IPCC) found that the warming of the climate system was "unequivocal and that a number of attendant effects were already observable (Pender 2008; United Nations Conference on Trade and Development (UNCTD) 2009). In a later definition, IPCC (2007) defines climate change as a change in the state of the climate that can be identified (e.g., by using statistical tests) by changes in the mean and /or the variability of its properties, and that persists for an extended period typically decades or longer. Similarly, Sandberg and Sandberg, (2010), define Climate change as the increase in temperatures and changes in weather patterns created by carbon and other greenhouse gas emissions.

Climate can change due to forces external to the climate system (e.g., arrangement of continents, volcanic eruptions, and changes in the intensity of sunlight). It can also change as a result of forces internal to the climate system (e.g., atmospheric composition, clouds), or because of anthropogenic (human-caused) changes (e.g., large-scale modifications of the land surface and atmospheric composition of greenhouse gases). Humans are however the major inducer and sufferers of climate change. In fact, the term 'Climate Change' commonly refers to influences on climate resulting from human practices. This is because increases in the concentration of greenhouse gases in the atmosphere resulting largely from burning of fossil fuels and deforestation, have led to an observed and projected warming of the earth, known as the enhanced greenhouse effect. This is why many scientists regard human-caused (anthropogenic) global climate change to be the most important environmental issue of our times (Cunningham and Cunningham, 2004).

The gases that contribute directly to the enhanced greenhouse effect as a result of anthropogenic activities are carbon dioxide (CO2), chlorofluorocarbons (CFCs), methane $\left(\mathrm{CH}_{4}\right)$ and nitrous oxide $\left(\mathrm{N}_{2} \mathrm{O}\right)$ emitted from combustion of fossil fuels, deforestation and agriculture, and sulphur hexafluoride (SF6) and perfluorocarbons arising from industrial processes. However, $\mathrm{CO}_{2}$ currently contributes the highest rate of the greenhouse gases followed by $\mathrm{CH}_{4}, \mathrm{CFCs} \mathrm{N}_{2} \mathrm{O}$ and others (like halons, tropospheric ozone, sulphuric hexafluoride (SF6) among others) (Odjugo, 2010). Some other gases, including carbon monoxide, nitrogen oxides and volatile organic compounds, contribute indirectly to global warming through chemical reactions in the atmosphere. Other emissions, such as sulfate aerosols have a cooling or dimming effect on the climate as they reflect some of the short-wave radiation before it reaches the earth's surface. 
The contribution of each of the greenhouse gases to global warming is dependent on its Global Warming Potential (GWP), expressed as carbon dioxide equivalent $\left(\mathrm{CO}_{2}\right.$ e). The GWP takes into account a number of things namely, the amount of radiation that the gas absorbs and the wavelength at which it absorbs; the time that the gas stays in the atmosphere before reacting or being dissolved in rainwater or the ocean; the current concentration of the gas in the atmosphere; and any indirect effects of the gas (e.g. methane will produce ozone gas in the lower atmosphere and water vapour in the stratosphere).

Many elements of human society and the environment are sensitive to climate variability and change. Human health, agriculture, natural ecosystems, coastal areas, and heating and cooling requirements are examples of climate-sensitive systems. Consequently, the manifestations of climate change will include extreme weather events in many parts of the world in the following ways:

* Higher frequency of formation of cyclonic storms;

* Higher intensity rainfall along with changing precipitation patterns; prolonged droughts

* Hurricanes along with related landslides and wildfires

* Sea level rise which mean that low -lying areas of the earth are potentially most vulnerable.

* Decreased water availability and increasing drought in mid-latitudes and semi-arid low latitudes;

* Decreased cereal productivity at low latitudes;

* Risk of extinction of global plant and animal species (up to $30 \%$ or even more depending on scenario);

* Increased warm spells, heat waves and heavy precipitation events; and

* Increased morbidity and mortality from changing weather patterns, changed disease vector distributions, and malnutrition (James Madison University, 2010).

\section{The Need for Mitigation and Adaptation}

Climate change mitigation is any action taken to permanently eliminate or reduce the long-term risk and hazards of climate change to human life and property. According to the International Panel on Climate Change (IPCC), mitigation is an anthropogenic intervention to reduce the sources or enhance the sinks of greenhouse gasses. On the other hand, climate change adaptation refers to the ability of a system to adjust to climate change (including climate variability and extremes) to moderate potential damage, to take advantage of opportunities, or to cope with the consequences. The IPCC defines adaptation as the adjustment in natural or human systems in response to actual or expected climatic stimuli or their effects, which moderates harm or exploits beneficial opportunities.

The effects of climate change are diverse and severe. Many elements of human society and the environment are sensitive to climate variability and change. Human health, agriculture, natural ecosystems, coastal areas, and heating and cooling requirements are examples of climate-sensitive systems. Consequently, the manifestations of climate change will include extreme weather events in many parts of the world as follows: higher frequency of formation of cyclonic storms; higher intensity rainfall along with changing precipitation patterns; prolonged droughts; hurricanes along with related landslides and wildfires; and sea level rise which mean that low -lying areas of the earth are potentially most vulnerable.

Other adverse effects of climate change include: decreased water availability and increasing drought in mid-latitudes and semi-arid low latitudes; decreased cereal productivity at low latitudes; risk of extinction of global plant and animal species (up to 30\% or even more depending on scenario); increased warm spells, heat waves and heavy precipitation events; and increased morbidity and mortality from changing weather patterns, changed disease vector distributions, and malnutrition (J ames Madison University, 2010) 
The specific effects of climate change according to Madu: 2011 include:

Frequent environmental disasters: Climate change induced disasters such as drought, floods, severe weather and sea-level rise and wild fire are likely to increase in intensity and frequency with the consequence increases in vector-borne diseases, infrastructure damage, the degradation of natural resources upon which livelihoods are based, food insecurity as well as loss of life and property.

Declining agricultural productivity: While higher Carbon-dioxide levels and solar radiation theoretically can increase food production, heat stress, shorter growing seasons and higher evapo-transpiration resulting in soil moisture levels being lowered counteract the former influences leading to overall lower production of most foodstuffs.

Insecurity and conflicts: Climate change may pose threat to the security situation in a country through increasing water scarcity; decreasing food security; increasing climate-induced migration; and the increase of poverty.

Health: Climate change has wide-ranging consequences on human health. This is because the health of communities depends on sufficient food, safe drinking water, comfortable homes, good social conditions, and a suitable environmental and social setting for controlling infectious diseases.

Thus, the major areas of climate change impacts are: Agriculture, water resources and the natural environment; Human health; Tourism and human welfare; Energy, transport and communication; Urban and rural settlements and sustainable development; and Economies and financial services (Madu: 2011). The importance of the above impact areas to individual and national lives cannot be over-emphasized hence the need for concerted efforts towards climate mitigation and adaptation.

While mitigation tackles the causes of climate change, adaptation tackles the effects of the phenomenon. The more mitigation there is, the less will be the impacts to which we will have to adjust, and the less the risks for which we will have to try and prepare. Conversely, the greater the degree of preparatory adaptation, the less may be the impacts associated with any given degree of climate change.

For developing countries, good adaptation and good development policy are very strongly intertwined, and it is right that climate change should now become central to national planning processes and to development assistance.

In summary, in the United Nations Framework Convention on Climate Change (UNFCCC), three conditions are made explicit when working towards the goal of greenhouse gas stabilization in the atmosphere:

1. That it should take place within a time frame sufficient to allow ecosystems to adapt naturally to climate change.

2. That food production is not threatened.

3. That economic development should proceed in a sustainable manner.

Therefore, to eliminate or reduce the risk of climate change to human life and property, both policy instruments and technology must be used in the context of sustainable development.

\section{Theology of Climate Change Mitigation and Adaptation: The Place of the Church}

In the Book of Genesis, where we find God's first self-revelation to humanity (Gen. 1-3), there is a recurring refrain: "And God saw that it was good." Mankind's first home Eden was paradise, hence it was good. Thus, the Earth was paradise, beaming and teaming with life, vegetation and the wondrous landscape of skies, the land and the sea. Nche (2012:76) has observed that:

An aesthetic look at the waters and its inhabitants, the flowers, the plants and the trees; as well as a topographic analysis of the lands, well structured hills, mountains and fearful valleys; and a critical study of the processes that bring rain; as well as the various climatic seasons would show how beautiful, the earth is. The earth was made for the inhabitation and sustenance of man and 
which in turn, should be sustained and preserved by man.

Creation in God's eyes was good, but at the same time he entrusted it to the care of man and woman. Adam and Eve's call was to participate in the unfolding of God's purpose for creation that is brought into play by the abilities and gifts which distinguishes human beings from all other creatures. The Lord called upon the first humans to tend this paradise and to keep it, in other words to take care of it. This call also established a fixed relationship between mankind and the rest of creation. Made in God's image and likeness, Adam and Eve were to have exercised their dominion over the earth with wisdom and love. Instead, they destroyed the existing harmony by deliberately going against the Creator's plan, that is by choosing to sin. The result is not only man's alienation from himself, in death and God, but also in the earth's "rebellion" against him (cf. Gen. 3:17-29.4:2). Through sin, all creation now become subject to futility, anticipating liberation together with all God's children (cf. Rom. 8:20-21).

As Christians, we believe that Jesus' Death and Resurrection has accomplished the work of reconciling humanity to the Father, who "was pleased (through Christ) to reconcile to himself all things, whether on earth or in heaven, making peace by the blood of his cross" (Col. 1:19-20). Creation once subjected to the bondage of sin and decay is now renewed in and through Christ. Thus, God the Father "has made known to us in all wisdom and insight the mystery which he set forth in Christ as a plan for the fullness of time, to unite all things in him, all things in heaven and things on earth" (Eph 1:9-10).

These biblical considerations help us understand better the relationship between human activity and creation, especially now as everyone seems to be talking about climate change. It's no longer just the concern of a few eco-warriors, it's in the media, is becoming a political issue and more and more individuals are becoming aware of their own carbon footprint. Through climate change one becomes more aware that when people turn their back on the Creator and his plan, by living a self-centered life of individualism, accumulation and consumption man provokes a disorder which has inevitable repercussions on the rest of the created order, such as that which many parts of the world have encountered and are encountering in these extreme weather events that have occurred in these recent years.

Corroborating the above point in relation to the role of the church, Williams, the Archbishop of Canterbury (2011) avers, "For the Church of the $21^{\text {st }}$ century, good ecology is not an optional extra but a matter of justice. It is therefore central to what it means to be a Christian". Jones (2009) also intones, "To say that creation is there for us to take advantage of is in the end to dethrone Christ for it is through him and for him all things came into being". The above statements strongly affirm that creation should not be exploited selfishly and unjustly.

The world faces a profound crisis of ecological disruption and depletion consequent upon man's selfish exploitation of it. A great collective effort from which the church cannot be excluded is needed to avert further climate change, to help and protect those who are suffering most acutely from environmental stress, to safeguard the earth's rich web of habitats and wildlife.

The Anglican Communion, especially in England, appears to have taken the lead in this direction. She has long recognized the need "to take all possible actions to ensure man's responsible stewardship over nature" (Lambeth Conference, 1968), coming to see stewardship as part of sustainable development: conserving the richness and health of environments and wildlife while advocating economic and social action that promotes justice and decent living standards for all. She has along this line drawn up a 7 year committed programme of ecological protection in 2009 which she has practically pursued till date.

According to Richard Chartres, Bishop of London (2011), "It is important to note that the biblical tradition goes beyond merely commending care for creation as it is, but also enrolls human beings as co-creators with God. This is what we assert every time we offer bread at the Eucharist as 'fruit of the earth and work of human hands". 


\section{Recommendations}

Based on the findings of this research as discovered above from the review of the biblical theology of ecological care the following recommendations aimed at stimulating a sense of commitment to the task of climate change mitigation and adaptation on the part of the church are put forward:

- The Church has in the past involved herself in many activities that helped to reduce human sufferings and promote more sustainable living. This time she should turn her attention towards the theological implications of environmental issues.

- The Church should develop a biblical theology of ecological protection with which she can enlighten people through public education that the earth is the theatre of God's grace therefore, as part of creation, we must also be actors in this theatre of grace for we are among the recipients of this grace and likewise we are also called to exhibit this grace in and towards creation by protecting and maintaining ecology.

- The Church has a special role in the life of the nation and as such, is uniquely placed to convene debate and encourage cooperation, and to work with other organizations for the common cause of climate change mitigation, adaptation and environmental care.

- The Church should ensure that climate change policies are balanced with poverty alleviation, employment creation and infrastructure development which will call for looking into linkages between trade and finance measures.

- The church can also put necessary mechanisms in place to ensure that funds provided by governments or other agencies really reach to those affected by climate change adversely, and not be channeled elsewhere.

- The Church can play great role in terms of organizing public education programs on climate change to enlighten both the rural and urban dwellers on the adverse effects of climate change. She can enlighten the people on what to do in order to reduce or eliminate the risk of climate change to human life and property. In other words the church should be actively involved in teaching the people about mitigation and adaptation strategies to help them cope with the effects of climate change.

\section{Conclusion}

None of the two anti-climate change effect measures - mitigation and adaptation - will be achieved easily. Nevertheless, the individuals and groups who make efforts towards providing a suitable environment for coping with climate change and its effects should draw strength and hope from the conviction that God cares for and sustains creation and has always acted to renew creation, and that human beings are mandated to serve joyfully and work with God as priests of creation.

The church is expected among other things to develop a sound biblical theology of climate change mitigation and adaptation and to dedicatedly disseminate same to her various denominations. The church should also develop a long term committed program of climate change mitigation and adaptation the implementation of which the various denominations and individual members should religiously be involved. Climate change mitigation and adaptation is undoubtedly a very important part of the calling of the church as ambassadors of God on earth.

\section{References}

Anyadike, R. (2009): Implications of Climate change for Economic Growth and Sustainable Development in Nigeria. A paper presented at the Enugu Forum organized by African Institute of Applied Economics, Enugu.

Australian Government's Cooperative Research Centres program http://www.co2crc.com.au/image /imagelibrary/gen_diag/greenhouseeffect_media.jpg. Assessed on 14 ${ }^{\text {th }}$ March 2013.

Bouma-Prediger, S. (2008), Beyond Homelessness, Grand Rapids: Eedermans 
Chartres, R. (2009), Church of England on Climate Change http://www.london.anglican.org>Home. Assessed on $18^{\text {th }}$ March 2013.

Cooperative Research Centre for Greenhouse Gas Technologies (CO2CRC)(2010): Greenhouse effect: Representation of the greenhouse effect .

Chuck Baclagon (2010): Evangelical Churches and Climate Change: A Call to Action http://faithseekingknowledge.wordpress.com. Assessed on 10th April 2013.

Church Care: (2009) Church and Climate Change-Action Plan of Church of England http://www.churchcare.co.uk.building.php. Assessed on 14th March 2013.

Church of England and Climate Justice: A Motion at General Synod http://www.churchofengland.org>Home>Views. Assessed on 10th March 2013.

Cunningham, W.P and Cunningham, M.A (2004): Principles of Environmental Science: Inquiry and Applications. McGraw-Hill, New York. 2nd Ed.

Hendrix, C and Salehyan, I. (2011): The Brewing Storm? Climate Change Rainfall and Social Conflicts in Africa. Climate Change and African Political Stability (CCAPS). Policy Brief No. 2 Fe b r u a r y 20 11.

Http: //www.ipcc.ch/pdf/assessment-report/ar4/syr/ar4_syr_spm.pdf. Assessed on 10th March 2013.

IPCC (2001), "Climate Change 2001: Impacts, Adaptation and Vulnerability", Working Group II Contribution to the Third Assessment Report of the Intergovernmental Panel on Climate Change, "Chapter 18: Adaptation to Climate Change in the Context of Sustainable Development and Equity", Cambridge University Press, Cambridge, pp. 877-912.

IPCC (2007). Intergovernmental Panel on Climate: The fourth assessment report (AR4). Synthesis report for policymakers.

James Madison University (2010), Climate Action Report, Virginia. JMU.

Jones, J. Bishop of Liverpool (2009), http://www.churchcare.co.uk/building.php. Assessed on 10th March 2013.

Kennedy, E (2008), Justice and the Heart of God, Oxford: Christian Aid http://faithseekingknowledge.wordpress.com. Assessed on 14th March 2013.

Madu, I.A (2011) Impacts of Climate Change in Nigeria - A paper presented at the Inaugural Workshop and Symposium for the Implementation of the Climate Change Adaption Capacity Programme at the University of Nigeria (16th March 2011).

Matthew Henry's (1991) Commentary on the Whole Bible, USA: Hendrickson Publishers.

Montalbo Jnr, M (1998), The Church Speaks on Peace, Manila: St. Paul http://faithseekingknowledge.wordpress.com. Assessed on 14th March 2013.

Nche, G.C. (2012) Challenges of Climate Change: The Role of Christian Religious Leaders. Journal of Educational and Social Research (Vol. 2) No. 10, pp. 73-80.

Odjugo,P A. (2010) : "General Overview of Climate Change Impacts in Nigeria". J. Hum Ecol, 29(1) pp 4755.

Pender, J.S. 2008. What is Climate Change? And how it will affect Bangladesh. Briefing Paper (Final draft) Dhaka Bangladesh .Church of Bangladesh Social Development Programme.

Sandberg L. A., and Sandberg, T. (2010): Introduction: Climate change - who's carrying the burden? In L. A. Sandberg and T. Sandberg(Eds), Climate Change-who's Carrying the Burden? The chilly climates of the global environmental dilemma. Third volume in the Our Schools/Our Selves book series 2010.0ttawa, Canadian Centre for Policy Alternatives

Schneider, N. (2008): Understanding Climate Change. Fraser Institute, Vancouver, British Columbia, Canada.

Williams, R. (2011) http://www.churchcare.co.uk/building.php. Assessed on 14th March 2013. 
